ISSN 2353-2912

1(6)2018

Ateneum-Szkoła Wyższa w Gdańsku

\title{
Forum Filologiczne ATENEUM
}

Ateneum Philological Forum

\author{
Pod redakcją \\ Katarzyny Kukowicz-Żarskiej

\section{SEARCH AND RESEARCH BADANIA I POSZUKIWANIA}

\section{A][ENEUM SZKOKA WYŻSZA
W GDANSSKU}

Gdańsk 2018 


\section{Komitet Wydawniczy:}

prof. zw. dr hab. Edmund Kotarski (przewodniczący), prof. nadzw. dr hab. Zdzisław Aleksander,

prof. nadzw. dr Hanna Dubrzyńska, prof. nadzw. dr hab. Marcin Krawczyński,

dr Katarzyna Kukowicz-Żarska, prof. nadzw. dr hab. Henryk Olszewski, prof. zw. dr hab. Waldemar Tłokiński, dr Bartosz Wiśniewski.

Redaktor naczelny: dr Katarzyna Kukowicz-Żarska, Ateneum-Szkoła Wyższa (Polska)

\section{Komitet Naukowy Czasopisma Forum Filologiczne Ateneum:}

\section{Filologia angielska}

Prof. Desmond Graham, The University of Newcastle, Newcastle upon Tyne (Wielka Brytania)

Prof. Henryk Kardela, Uniwersytet M. Curie-Skłodowskiej w Lublinie (Polska)

Prof. Tom Napieralski University of Colorado, Colorado Springs (Stany Zjednoczone)

Prof. Piotr Stalmaszczyk, Uniwersytet Łodzki (Polska)

Filologia włoska

Prof. Mercedes Arriaga Florez, Universidad de Seville (Hiszpania)

Prof. Dario Tomasello, Universita degli Studi di Messina (Włochy)

Prof. Maria Rosaria Vitti-Alexander, College Nazareth-Rochester (Stany Zjednoczone)

Filologia hiszpańska

Prof. Antonio Pamies Bertran (Universidad de Granada) (Hiszpania)

Prof. Luis Luque Toro (Universita Ca’ Foscari, Venezia) (Włochy)

Dr Lucia Luque Nadal (Universidad de Cordoba) (Hiszpania)

Filologia germańska

Prof. zw. dr hab. Grażyna Łopuszańska-Kryszczuk, Uniwersytet Gdański (Polska)

Prof. zw. dr hab. Mariola Wierzbicka, Uniwersytet Rzeszowski (Polska)

\section{Recenzja tomu}

Prof. Rafael Lopez-Campos Bodineau, Universidad de Seville (Hiszpania)

Redaktorzy języka angielskiego: Dorota Skowrońska, Arkadiusz Janczyło

Redaktor języka hiszpańskiego: Fernando Torrens

Redaktor języka włoskiego: Linda Balistreli

\section{ISSN 2353-2912}

(C) Copyright by „Ateneum-Szkoła Wyższa” w Gdańsku 2019

Pierwotna wersja czasopisma drukowana.

\section{Adres Redakcji:}

„Ateneum - Szkoła Wyższa” w Gdańsku, ul. 3 Maja 25A, 80-802 Gdańsk

e-mail: wydawnictwo@ateneum.edu.pl

Wydawnictwo: Ateneum - Szkoła Wyższa w Gdańsku

Przygotowanie do druku: Violetta Pastwa

Projekt okładki: Katarzyna Krawczyńska

Druk i oprawa: SOWA Sp. z o.o., 05-500 Piaseczno, Raszyńska 13

Nakład 100 egz. 


\section{Spis treści}

Słowo wstępne

\section{LINGUISTICS}

Mercedes ARRIAGA FLOREZ, Interlinguistic crosses and transextuality

Daniele CERRATO,

in María Rosal

Alessia DELLA ROCCA

Marzena GUZ

Niemieckie ślady w reportażach Melchiora

Wańkowicza z tomu „Anoda i katoda”. Reportaże

z części „Kraj lat dziecinnych” w perspektywie

leksykalnej

Arkadiusz JANCZYŁO

In search of image manipulation mechanisms

in a public person's speech interpretation

- a case study

Agnieszka ŁAZOR

Influencia de las lenguas prerromanas

en la lengua española

Katarzyna KUKOWICZ-ŻARSKA O wartościowaniu i prawdzie w języku i tekście.

Język narodowego socjalizmu w perspektywie językoznawczej i socjokulturowej....

Melisa MARAS

Egzotyzacja i domestykacja w polskim tłumaczeniu

powieści „Harry Potter i Kamień Filozoficzny”

J. K. Rowling.

Dorota SKOWROŃSKA

Constructed Languages of Hildegard of Bingen and Suzzette Haden Elgin. Female Empowerment through Language? 101

Agata ZAPŁOTNA

La vitalità del congiuntivo nel linguaggio televisivo 113

\section{LANGUAGE TEACHING}

Anna HERRA, Anna KULIŃSKA The role of feedback in the process of learning

English as a foreign language 
Karolina JANOWSKA

Janusz KAWKA

Renata MAJEWSKA

Katarzyna WALKOWSKA
Evolución de la metodologia de la enseñanza

de las lenguas extranjeras 145

Identyfikacja i klasyfikacja błędów językowych

na lektoracie języka niemieckiego

Autonomia w klasach dwujęzycznych: sprawozdanie z badań jakościowych

Interkulturelles Lernen und Lehren

im Fremdsprachenunterricht - warum, wozu

und wie? 187

\section{CRITICAL PERSPECTIVES}

Marta ZUBACZ,

Maurizio BONINO

\section{REPORTS}

Dorota SKOWROŃSKA
La leggenda del regno del Prete Gianni...... 205
Report on the Language Show, London, 9-11 November 2018 225

Notki o autorach 229 


\section{Słowo wstępne}

Oddajemy w Państwu ręce kolejny tom naszego czasopisma. Za motyw przewodni niniejszego tomu obraliśmy badania $i$ poszukiwania $\mathrm{w}$ szerokim kontekście filologicznym. Gwarantem rozwoju nauki, w naszym mniemaniu, jawi się dociekliwość badawcza, poszukiwanie nowej myśli czy ścieżki naukowej, a jej następstwem wnikliwe i rzetelnie prowadzone badania. Te idee przyświecają także autorom, prezentującym na łamach naszego czasopisma swe aktualne zainteresowania i osiągnięcia naukowe.

Gros artykułów zawartych w niniejszym woluminie stanowią rozważania językoznawcze, które dla większej przejrzystości uszeregowane zostały w kategoriach: językoznawstwo, nauczanie języka, analiza krytyczna. $\mathrm{W}$ przedstawianym tomie pojawia się także sprawozdanie $\mathrm{z}$ wydarzenia, jakim jest Language Show w Londynie. Autorzy prezentując swą własną interpretację głównej myśli tomu pozwalają nam zagłębić się w prowadzone przez siebie badania i poszukiwania na szeroko rozumianym polu języka.

Prof. Mercedes Arriaga Florez, dr Daniele Derrato oraz mgr Alessia Della Rocca analizują różne strategie tekstowe, przy pomocy których María Rosal Nadales tworzy transtekstualną konstrukcję w swojej antologii „Al este del andén”. Autorzy przybliżają zastosowanie tej techniki, mającej być odpowiedzią na szereg zagadnień, takich jak np. aktywna rola czytelnika w procesie recepcji tekstu, efekt zaskoczenia i ironii, postmodernistyczna fuzja kultury klasycznej i popularnej, etyczno-estetyczne zobowiązanie do wskazywania sprzeczności, tworzenia nowych metafor czy wreszcie wpływania na recypienta, zachęcając go do refleksji i kreowania nowych sposobów myślenia. 
Prof. Marzena Guz bada z perspektywy leksykalnej niemieckie ślady w reportażach Melchiora Wańkowicza z tomu „Anoda i katoda”. Autorka przedstawia słownictwo mające na sobie piętno wpływów niemieckich oraz słownictwo polskie odnoszące się do Niemiec, jak również sposoby polonizacji prezentowanego materiału leksykalnego.

Mechanizmy manipulowania w przestrzeni publicznej analizuje mgr Arkadiusz Janczyło. Prezentowane studium przypadku opiera się na jakościowej analizie mowy osoby publicznej, którą jest tu Lech Wałęsa, wraz z jej językiem i tłumaczeniem. Autor bada także sposoby, jakimi w przestrzeni publicznej można manipulować ową mową i jej tłumaczeniem, aby stworzyć określony wizerunek publiczny.

Mgr Agnieszka Łazor analizuje wpływ języków przedromańskich na język hiszpański, argumentując, iż choć przed romanizacją Półwysep Iberyjski był zamieszkany przez społeczności posługujące się odrębnymi językami, a językiem urzędowym był łacina, to jednak kontakt języków lokalnych z łaciną pozostawił ślady zachowane we współczesnym języku hiszpańskim.

Dr Katarzyna Kukowicz-Żarska zajmuje się w swej publikacji tematyką wartościowania w języku i tekście oraz akcentuje pojawiającą się w tym kontekście relację prawda-fałsz. Podstawę dla tych rozważań tworzy język narodowego socjalizmu, analizowany w perspektywie językoznawczej i socjokulturowej. Autorka postrzega tekst i jego rolę przez pryzmat wartości w kontekście uniwersalnym, ale także przez pryzmat reprezentowanych w nim językowych środków wartościowania i metod oceny.

Mgr Melisa Maras bada zjawiska egzotyzacji i domestykacji w polskim tłumaczeniu powieści „Harry Potter i Kamień Filozoficzny” J. K. Rowling. Autorka zmaga się z pytaniem o intencje użycia udomowienia i egzotyzacji, przyświecające Andrzejowi Polkowskiemu przy tłumaczeniu omawianej serii, a wybrane fragmenty powieści, dotyczące szerokiej kategorii jedzenia, analizuje w szerszym kontekście językowo-kulturowym.

Mgr Dorota Skowrońska przedstawia języki sztuczne Hildegardy z Bingen i Suzzette Haden Elgin i stawia w tym kontekście pytanie o możliwość wzmocnienia pozycji kobiety poprzez język. Autorka bada możliwe klasyfikacje lingua ignota i Láadan oraz ich cechy gramatyczne, leksykalne i fonologiczne, stawiając sobie jednocześnie za cel ukazanie sukcesu języków sztucznych w stosunku do ich założenia pierwotnego lub sugerowanego przez samych ich twórców, jak również celów ogólnie ustalonych dla tego typu języków. 
Mgr Agata Zapłotna ukazuje efekt swych badań w zakresie włoskiego języka telewizji. Autorka argumentuje, iż język telewizyjny jest obecnie uważany za odzwierciedlenie włoskich odmian i języka mówionego, a mimo tego nadal istnieje heterogeniczny język tego typu. Jako taki stanowi on zbiór różnych stylów i rejestrów, charakteryzujących się odmiennymi zjawiskami językowymi niż mowa bez nadzoru.

Tematykę nauczania języka obcego podejmują mgr Anna Herra i dr Anna Kulińska, badając rolę informacji zwrotnej $\mathrm{w}$ procesie nauczanie języka angielskiego jako obcego. Autorki podkreślają rolę informacji zwrotnej jako relewantnego elementu interakcji uczeń-nauczyciel, służącego zrozumieniu indywidualnych potrzeb ucznia jako podmiotu procesu nauczania języka obcego. Informacja taka pozwalać ma, zdaniem autorek, na dostosowanie instrukcji, ocen i komentarzy, by wspierać tym samym ucznia w nauce języka.

Mgr Janusz Kawka podejmuje tematykę identyfikacji i klasyfikacji błędów językowych w procesie nauczania języka niemieckiego. Autor analizie błędów przypisuje istotną funkcję, służącą zarówno celom pedagogicznym, jak i psycholingwistycznym, która udzielić ma uczącemu odpowiedzi na pytanie, jakie treści nauczania zostały już opanowane, a na jakiej płaszczyźnie występują jeszcze deficyty.

Próby przeglądu najpopularniejszych technik i metod nauczania języków obcych w Europie dokonała mgr Karolina Janowska, zwracając przy tym uwagę na ciągłe zmiany metodologiczne $\mathrm{w}$ tym zakresie, mające wynikać $\mathrm{z}$ poszukiwania idealnej metody nauczania. Autorka silnie akcentuje współczesne podejście do nauki języka, jako zapewniające uczniom idealne możliwości rozwoju umiejętności komunikacyjnych i skutecznego uczenia się.

Dr Renata Majewska prezentuje przebieg i wyniki badań jakościowych, dotyczących rozwoju kompetencji dyskursywnej w warunkach półautonomii w oddziałach dwujęzycznych z językiem hiszpańskim. Autorka dzieli się także szerszą refleksją nad sposobami rozwijania autonomii wśród uczniów takich właśnie klas.

Tematykę interkulturowości w procesie nauczania i uczenia się języka obcego na podjęła dr Katarzyna Walkowska, starając się udzielić odpowiedzi na pytania, dlaczego, w jakim celu i w jaki sposób może być ona realizowana na lekcjach języka obcego.

Mgr Maurizio Bonino wraz z mgr Martą Zubacz mierzą się z gatunkiem tekstu jakim jest średniowieczna legenda. Rozważania oparte na analizie „Listu 
Jana Prezbitera”, z którego narodziła się legenda o królestwie Księdza Jana, obejmują zarówno aspekty historyczne, kulturowe jak i językowe, ukazują zgodność treści listu ze średniowiecznym obrazem świata, podejmują tematykę wpływu omawianego tekstu na ówczesnego odbiorcę, ewolucję formy oraz akcentują jego rolę jako inspiracji dla powstawania kolejnych utworów.

Życzymy miłej lektury.

Katarzyna Kukowicz-Żarska 